\title{
ASSESSING GENETIC DIVERSITY OF MAIZE (Zea mays L.) GENOTYPES FOR AGRONOMIC TRAITS
}

\section{Shanjida Rahman*, Md. Mukul Mia, Tamanna Quddus, Lutful Hassan and Md. Ashraful Haque}

Department of Genetics and Plant Breeding, Faculty of Agriculture, Bangladesh Agricultural University, Mymensingh- 2202, Bangladesh

*Corresponding author: Shanjida Rahman; E-mail: shanjidashaki@yahoo.com

\section{ARTICLE INFO ABSTRACT}

$\begin{array}{ll}\begin{array}{l}\text { Received } \\ \text { 07.03.2015 }\end{array} & \begin{array}{l}\text { Maize is one of the most important cereals globally and a promising cereal } \\ \text { supplement in Bangladesh. The current study was undertaken to assess genetic } \\ \text { diversity among nine maize genotypes. Data were recorded on seven morphological } \\ \text { Accepted }\end{array} \\ \begin{array}{l}\text { traits viz. plant height }(\mathrm{cm}) \text {, ear height }(\mathrm{cm}) \text {, ear length }(\mathrm{cm}) \text {, ear diameter }(\mathrm{cm}) \text {, } \\ \text { number of kernels/ear, 1000-kernel weight }(\mathrm{g}) \text { and yield/plant }(\mathrm{g}) \text {. Statistical analysis } \\ \text { showed significant variation among maize genotypes. Considering plant height, ear }\end{array} \\ \begin{array}{l}\text { Online } \\ \text { length, ear diameter, ear height, number of kernels/ear and yield/plant BHM-7 was }\end{array} \\ \text { observed as the best one. Among all the traits higher phenotypic coefficient of } \\ \text { Key words } & \begin{array}{l}\text { variation and genotypic coefficient of variation were observed for yield/plant. Genetic } \\ \text { Genetic diversity }\end{array} \\ \text { advance was highest for 1000-kernel weight followed by number of kernels/ear. The } \\ \text { correlation study revealed only two positive significant associations: plant height with } \\ \text { Genotype } \\ \text { Maize }\end{array}$

To cite this article: S Rahman, MM Mia, T Quddus, L Hassan and MA Haque. 2015. Assessing genetic diversity of maize (Zea mays L.) genotypes for agronomic traits. Res. Agric. Livest. Fish. 2 (1): 53-61. 


\section{INTRUDUCTION}

Maize is an amazing crop throughout the world which occupies a large portion of world economy. Total maize production in the world for the 2013-14 is 959 million tons which is more than that of wheat (709 million tons) and rice (473 million tons) (GMR 2014). In 2009, over 159 million hectares of maize were planted worldwide which gave a yield of 5.12 tons/ha (FAOSTAT, 2009). From nutritional view point it is better than rice and wheat (http://ndb.nal.usda.gov/ndb/search/list). Maize is also important in industrial and medicinal uses. In Bangladesh maize is considered as second most important cereal crop which occupies 165.5 thousand hectares land and produces 1018 thousand metric tons with an average yield of 6.1 tons/ha (BBS, 2011). The main use of maize is as poultry feed (Hossain and Shahjahan, 2007). In Bangladesh current need of maize is 1.60 million metric tons annually (Ahmed, 2013). If the traditional prolonged rice dependent food habit of Bangladesh can be diversified with maize, it would probably be possible to attain foodself sufficiency to a great extent. Because, it is a high yielding and low-cost crop compared to rice and wheat. For satisfying this purpose, diversity assessment of existing genotypes would provide valuable inputs to move forwarding with the current and upcoming breeding needs.

Genetic diversity is the variation of heritable characteristics in genetic makeup present in a population of the same species. Knowledge of diversity in a germplasm is very important for the improvement of crop plants through breeding program (Hallauer et al., 1988). Different methods can be used to assess genetic diversity in plant species, such as pedigree and heterosis data, morphological marker and molecular markers (Melchinger, 1999; Xia et al., 2005; Legesse et al., 2007). Morphological traits are the earliest, convenient and effective genetic markers used for germplasm management (Statonet al., 1994). Morphological markers is of great value in studies of maize landraces (Galarreta and Alvarez, 2001; Lucchin et al., 2003; Ortiz et al., 2008). Both qualitative and quantitative traits have been considered to study phenotypic diversity of maize (Alika et al., 1993; Taba et al., 1998; Lucchin et al., 2003). The most commonly used parameters are related to plant architecture traits, tassel traits, ear and kernel characteristics. The variables contributing to genetic diversity are grain weight and grain yield (Hoque, 2008); kernel weight and days to maturity (Ahmed, 2007); ear height, days to silking, \% tryptophan content, cob length and 1000-seed weight (Kadir, 2010); ear length and diameter (Ahmed, 2013). The present investigation was conducted to analyze genetic diversity of maize genotypes using morphological traits.

\section{MATERIALS AND METHODS}

\section{Experimental site, duration and materials}

The experiment was conducted in the field lab of the Department of Genetics and Plant Breeding, Bangladesh Agricultural University (BAU), Mymensingh from March 2013 to April 2014. Nine maize genotypes were selected as experimental materials, those were: Uttaran, Duranta, BARI Hybrid Maize 5 (BHM-5), BARI Hybrid Maize 7 (BHM-7), BARI Hybrid Maize 9 (BHM-9), V-92, H-981, Pop Corn and Sweet Corn. All of them were collected from Bangladesh Agricultural Research Institute (BARI).

\section{Experimental design and data collection}

The experiment was conducted following randomized complete block design (RCBD) with three replications. The plot size was $4.2 \mathrm{~m} \times 2.7 \mathrm{~m}$, row to row and plant to plant distances were $60 \mathrm{~cm}$ and $30 \mathrm{~cm}$, respectively. Recommended production packages i.e. application of recommended doses of fertilizers, weeding, thinning, irrigation, pesticide etc. was followed as per BARI recommendation, as and when necessary to ensure the optimum plant growth and development.

At field maturity, five randomly selected plants were used for recording observations on the traits: plant height $(\mathrm{cm})$, ear height $(\mathrm{cm})$, ear length $(\mathrm{cm})$, ear diameter $(\mathrm{cm})$, number of kernels/ear, 1000-kernel weight $(\mathrm{g})$ and yield/plant $(\mathrm{g})$. Analysis of variance (ANOVA) was done on the sample for all the seven character mentioned using MStat-c statistical program. The total variance of each character was partitioned into replication, genotype and error. The differences within the classes of effects were tested by F-test. The mean performance of the nine genotypes for their traits was shown through lettering by DMRT (Duncan's Multiple Range Tests) using the same software. 
Genotyping and phenotypic variances were estimated according to the formula given by Johnson et al., (1995).

Genotypic variance, $\sigma_{g}^{2}=\frac{\text { GMS-EMS }}{r}$

Where,

GMS = Genotypic mean square, EMS= Error mean square

$r=$ Number of replication, Phenotypic variance, $\sigma^{2} \mathrm{ph}=\sigma_{\mathrm{g}}^{2}+\mathrm{EMS}$

Where,

$\sigma^{2} \mathrm{~g}=$ Genotypic variance

EMS = Error mean square

Heritability in broad sense $\left(\mathrm{h}^{2} \mathrm{~b}\right)$ was estimated according to the formula suggested by Johnson et al. (1995) and Hanson et al. (1956).

Heritability, $h^{2}{ }_{b}=\left(\sigma^{2} g / \sigma^{2} \mathrm{ph}\right) \times 100$

Where,

$\sigma^{2} g=$ Genotypic variance, $\sigma^{2}$ ph $=$ Phenotypic variance

Genotypic and phenotypic co-efficient of variations were estimated according to Burton (1952) and Singh and Chaudhary (1985).

Genotypic co-efficient of variations, GCV $=\frac{\sqrt{\sigma^{2} g}}{\bar{X}} \times 100$

Where,

$\sigma^{2} g=$ Genotypic variance; and $\bar{X}=$ Population mean

Phenotypic co-efficient of variations, PCV $=\frac{\sqrt{\int \sigma^{2} p h}}{\bar{X}} \times 100$

Where,

$\sigma^{2}$ ph $=$ Phenotypic variance; and

$\bar{X}=$ Population mean

Estimation of genetic advance was done following formula given by Johnson et al. (1955) and Allard (1960).

Genetic advance, $\mathrm{GA}=\mathrm{h}^{2} \mathrm{~b} . \mathrm{K} . \sigma_{\mathrm{p}}$

Where, $\mathrm{h}^{2} \mathrm{~b}=$ Heritability

$\mathrm{K}=$ Selection differential, the value of which is 2.06 at $5 \%$ selection intensity

$\sigma_{p}=$ Phenotypic standard deviation

Genetic advance in percent of mean was calculated by the formula of Comstock and Robinson (1952) as follows:

Genetic advance in percentage of mean, GA $(\%)=\frac{G A}{\bar{X}} \times 100$

Where,

$\mathrm{GA}=$ Genetic advance, $\bar{X}=$ Population mean

The correlation coefficient $(r)$ between two variables such as $X$ and $Y$ can be estimated using following formula:

$r_{\mathrm{xy}}=\frac{\sum \mathrm{XY}-\frac{\sum \mathrm{X} \sum \mathrm{Y}}{\mathrm{N}}}{\sqrt{\sum \mathrm{Y}^{2}-\frac{\left(\sum \mathrm{Y}\right)^{2}}{\mathrm{~N}}} \sqrt{\sum \mathrm{X}^{2}-\frac{\left(\sum \mathrm{X}\right)^{2}}{\mathrm{~N}}}}$

Where,

$\sum X Y-\frac{\sum X \sum Y}{N}=$ Sum of products of $X$ and $Y$

$\sqrt{\sum \mathrm{Y}^{2}-\frac{\left(\sum \mathrm{Y}\right)^{2}}{\mathrm{~N}}}=$ Sum of squares of $\mathrm{Y}$

$\sqrt{\sum X^{2}-\frac{\left(\sum X\right)^{2}}{N}}=$ Sum of squares of $X$ 
The genotypes were arranged in different clusters followed by the method suggested by Ward's Method based on Squared Euclidean distance and hierarchical cluster analysis. The initial cluster distances in Ward's minimum variance method are therefore defined to be the squared Euclidean distance between points:

$d_{i j}=d\left(\left\{X_{i}\right\},\left\{X_{j}\right\}=\left\|X_{i}-X_{j}\right\|^{2}\right.$

\section{RESULT}

The analyses of variance of different genotypes of maize for different agronomic traits are shown in Table 1. It indicated that the difference among genotypes for all the traits under study viz., plant height $(\mathrm{cm})$, ear height $(\mathrm{cm})$, ear length $(\mathrm{cm})$, ear diameter $(\mathrm{cm})$, number of kernels/ear, 1000-kernel weight $(\mathrm{g})$ and yield/plant (g) was highly significant.

Table 1.Analysis of Variances (mean squares) for different characters of nine genotypes of maize

\begin{tabular}{|c|c|c|c|c|c|c|c|c|}
\hline $\begin{array}{l}\text { Source of } \\
\text { variation }\end{array}$ & $\begin{array}{l}\text { Degrees } \\
\text { of } \\
\text { freedom } \\
\text { (df) }\end{array}$ & $\begin{array}{l}\text { Plant } \\
\text { height } \\
(\mathrm{cm})\end{array}$ & $\begin{array}{c}\text { Ear } \\
\text { height } \\
(\mathrm{cm})\end{array}$ & $\begin{array}{c}\text { Ear } \\
\text { length } \\
(\mathrm{cm})\end{array}$ & $\begin{array}{c}\text { Ear } \\
\text { dia- } \\
\text { meter } \\
(\mathrm{cm})\end{array}$ & $\begin{array}{c}\text { Number } \\
\text { of } \\
\text { kernels/ } \\
\text { ear }\end{array}$ & $\begin{array}{l}1000 \text { kernel } \\
\text { weight } \\
\text { (g) }\end{array}$ & $\begin{array}{c}\text { Yield/ } \\
\text { plant } \\
\text { (g) }\end{array}$ \\
\hline Replication & 2 & 37.33 & 5.82 & 2.22 & 0.13 & 81.93 & 1.79 & 0.46 \\
\hline Genotype & 8 & $\underset{* *}{1105.17}$ & $\underset{* *}{82.95}$ & $\underset{* *}{11.29}$ & $\underset{* *}{0.74}$ & $\underset{*}{5459.12^{*}}$ & $\underset{* *}{10016.53}$ & $\begin{array}{c}1510 . \\
9^{* *}\end{array}$ \\
\hline Error & 16 & 3.67 & 6.57 & 0.62 & 0.04 & 97.01 & 0.96 & 1.53 \\
\hline
\end{tabular}

Trait-wise mean performance of the genotypes

Trait-wise mean performance of genotypes gives a clear comparison among genotypes. The mean performance of the nine genotypes for their traits with lettering by DMRT (Duncan's Multiple Range Tests) is shown in Table 2.

Table 2.Mean performance of nine genotypes of maize based on different agronomic traits

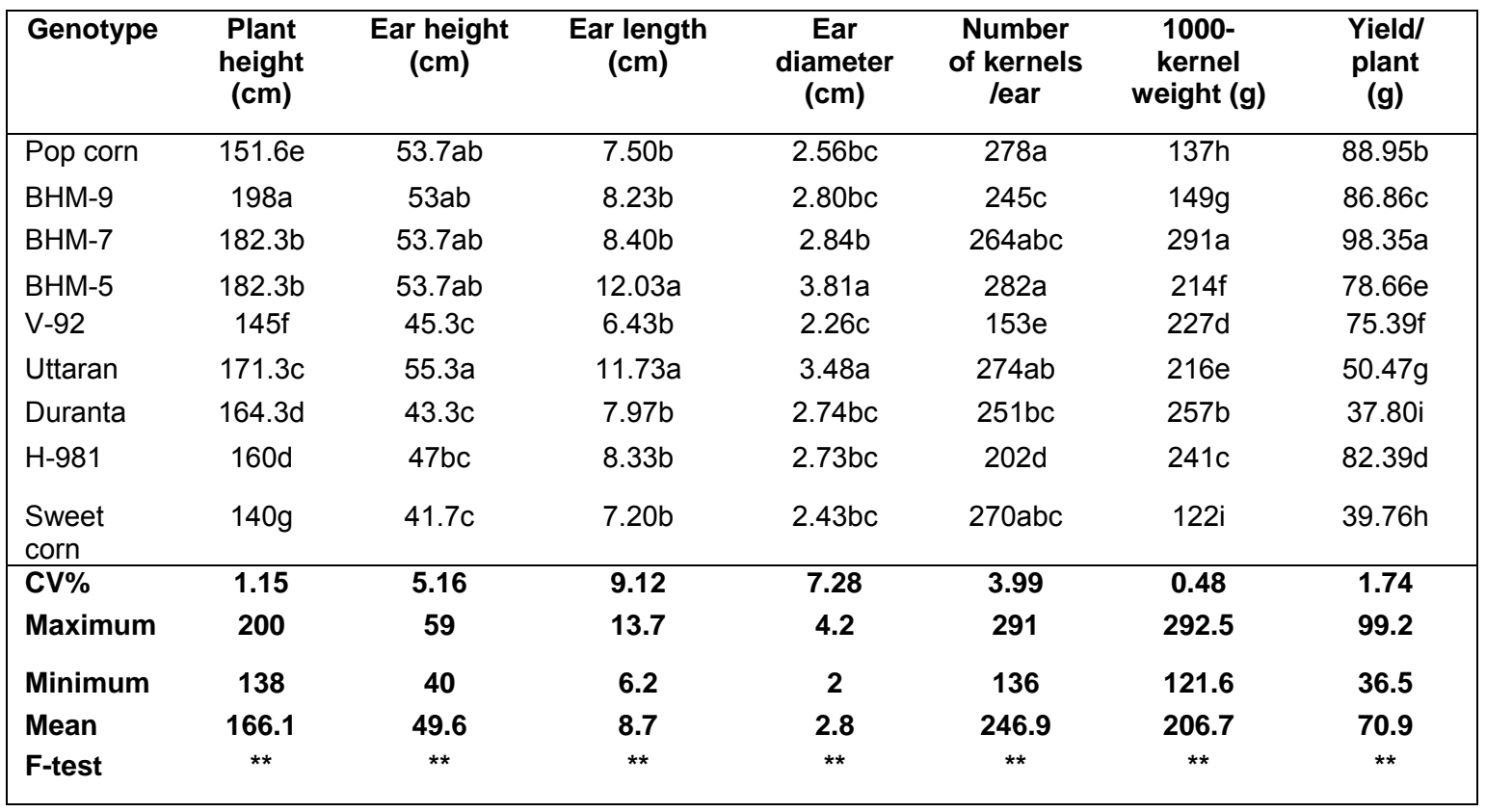

Note: $\mathrm{CV}(\%)=$ Coefficient of variation, ${ }^{* *}$ indicate significant at $1 \%$ level of probability

Similar letter indicates there is no significant difference at $5 \%$ level of probability as per DMRT

Different letter indicates significant difference at $5 \%$ level of probability 


\section{Estimation of correlation co-efficient}

The correlation value denotes only the nature and extent of association existing among characters. In this experiment, two associations showed positive significant correlation: plant height with yield/plant and ear diameter with ear length (Table 3). In the current study, only one negative association had been observed for number of kernels/ear with 1000-kernel weight which is non-significant.

Table 3. Correlation co-efficient between yield and other yield related characters

\begin{tabular}{|c|c|c|c|c|c|c|}
\hline Characters & $\begin{array}{l}\text { Plant } \\
\text { height }(\mathrm{cm})\end{array}$ & $\begin{array}{l}\text { Ear height } \\
(\mathrm{cm})\end{array}$ & $\begin{array}{l}\text { Ear length } \\
(\mathrm{cm})\end{array}$ & $\begin{array}{l}\text { Ear } \\
\text { diameter }(\mathrm{cm})\end{array}$ & $\begin{array}{l}\text { Number of } \\
\text { kernels/ear }\end{array}$ & $\begin{array}{l}\text { 1000-kernel } \\
\text { weight }(\mathrm{g})\end{array}$ \\
\hline $\begin{array}{l}\text { Ear height } \\
\text { (cm) }\end{array}$ & 0.606 & & & & & \\
\hline $\begin{array}{l}\text { Ear length } \\
\text { (cm) }\end{array}$ & 0.500 & 0.515 & & & & \\
\hline $\begin{array}{l}\text { Ear diameter } \\
(\mathrm{cm})\end{array}$ & 0.568 & 0.539 & $0.969^{* *}$ & & & \\
\hline $\begin{array}{l}\text { Number of } \\
\text { kernels/ear }\end{array}$ & 0.320 & 0.410 & 0.530 & 0.553 & & \\
\hline $\begin{array}{l}\text { 1000-kernel } \\
\text { weight (g) }\end{array}$ & 0.246 & 0.050 & 0.177 & 0.198 & -0.263 & \\
\hline $\begin{array}{l}\text { Yield/plant } \\
\text { (g) }\end{array}$ & $0.906^{* *}$ & 0.513 & 0.522 & 0.574 & 0.175 & 0.447 \\
\hline
\end{tabular}

** indicate significant at $1 \%$ level of probability

\section{Estimation of genetic parameters of maize genotypes}

Genotypic variances, phenotypic variances, heritability, genotypic co-efficient of variation (GCV), phenotypic co-efficient of variation (PCV), genetic advance and genetic advance (GA) as percent of mean (GA $\%)$ for all the yield contributing traits are presented in Table 4. Among the all traits yield/plant exhibited high estimates of GCV (31.61\%), PCV (31.66\%) and highest value of genetic advance in percentage $(62.47 \%)$. On the other hand highest heritability (99.97\%) and genetic advance (113.23) was observer in 1000-kernel weight.

Table 4. Genetic parameters of seven different characters of nine maize genotypes

\begin{tabular}{|lccccccc|}
\hline \multicolumn{1}{|c}{ Traits } & $\begin{array}{c}\text { Phenotypic } \\
\text { variance }\end{array}$ & $\begin{array}{c}\text { Genotypic } \\
\text { variance }\end{array}$ & PCV (\%) & $\begin{array}{c}\text { GCV } \\
\text { (\%) }\end{array}$ & $\begin{array}{c}\text { Heritability } \\
\text { (\%) }\end{array}$ & GA & GA (\%) \\
\hline $\begin{array}{l}\text { Plant Height } \\
\text { (cm) }\end{array}$ & 370.84 & 367.17 & 11.59 & 11.54 & 99.00 & 37.89 & 22.81 \\
$\begin{array}{l}\text { Ear height } \\
\text { (cm) }\end{array}$ & 32.03 & 25.46 & 11.40 & 10.17 & 79.49 & 8.92 & 17.97 \\
$\begin{array}{l}\text { Ear length } \\
\text { (cm) }\end{array}$ & 6.67 & 6.05 & 29.86 & 28.44 & 90.70 & 3.75 & 43.36 \\
$\begin{array}{l}\text { Ear diameter } \\
(\mathrm{cm})\end{array}$ & 0.27 & 0.23 & 18.22 & 16.82 & 83.94 & 0.88 & 30.86 \\
$\begin{array}{l}\text { No. of } \\
\text { kernels/ear }\end{array}$ & 1884.38 & 1787.37 & 17.58 & 17.14 & 94.85 & 81.96 & 33.19 \\
$\begin{array}{l}1000-k e r n e l \\
\text { weight (g) }\end{array}$ & 3339.49 & 3338.52 & 27.98 & 27.97 & 99.97 & 113.23 & 54.82 \\
Yield/plant(g) & 504.67 & 503.14 & 31.66 & 31.61 & 99.97 & 44.33 & 62.47 \\
\hline
\end{tabular}

GCV = Genotypic co-efficient of variation, $P C V=$ Phenotypic co-efficient of variation,

$\mathrm{GA}=$ Genetic advance, $\mathrm{GA} \%=$ Genetic advance as percent 


\section{Dendrogram}

In the present experiment, dendrogram of nine maize lines had been made using mean value of different agronomic traits which results in three clusters (Fig. 1).

\section{Dendrogram}

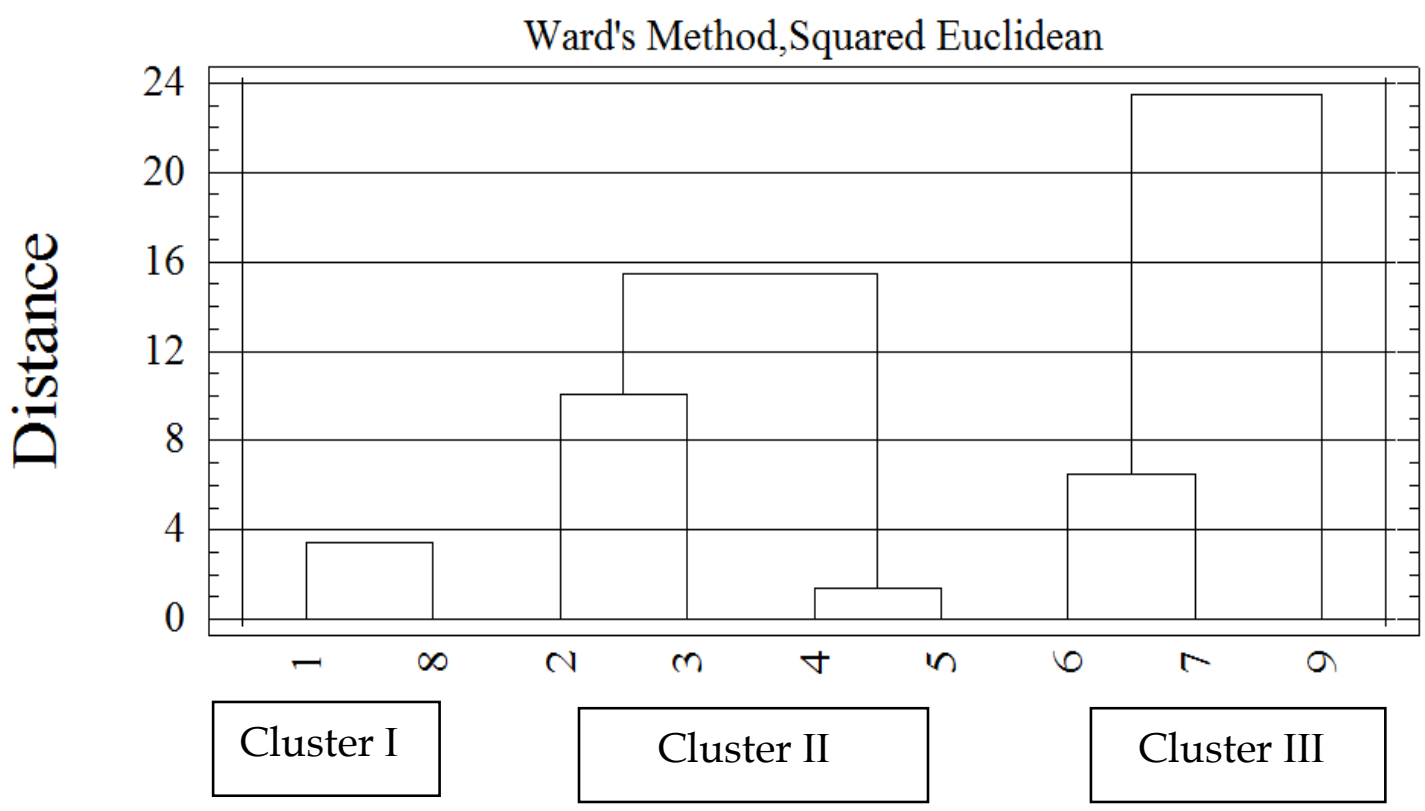

Figure 1. Dendrogram showing distribution of nine genotypes among three clusters

Table 5. Distribution of nine maize genotypes among three clusters

\begin{tabular}{|ccc|}
\hline Cluster & No. of Genotypes & Genotypes \\
\hline I & 2 & Popcorn, H-981 \\
II & 4 & BHM-9, BHM-7, BHM-5, V-92 \\
III & 3 & Uttaran, Duranta, Sweet corn \\
\hline
\end{tabular}

\section{DISCUSSION}

Analysis of genetic diversity is an important step for better understanding and utilization of germplasm. Maize is a diverse and highly cross pollinated crops. There exists a good number of work on genetic diversity of maize but the genotypes experimented in this study were not studied yet. We found wide array of diversity among these genotypes. The ANOVA table suggested presence of ample genetic variability among the genotypes. Shahrokhi and Khorasani (2013) also observed significant variation among genotypes for days to silking, days to anthesis, plant height, ear height, kernel number, rows number, 1000-kernel weight and yield. Ahmed (2013) also observed significant variation among maize genotypes for yield, ear length, ear diameter, number of kernels/ear, 1000-kernel weight, days to maturity, days to silking, plant height and ear height. Prasannaet al. (2001) noted that genetic variability for most of the yield and yield contributing traits in maize were very high and amenable to genetic enhancements.

The presence of a wide range between minimum and maximum values for each trait assures the existence of sustainable variation among the genotypes studied (Table 2). Such variation in the germplasm collection of maize is an opportunity for breeders to improve traits of interest through parent selection, hybridization and recombination of desirable genotypes (Ahmed, 2013). In this experiment, each trait indicated separate genotype as best one, such as BHM-9 considering plant height; BHM-5 considering ear length, ear diameter and number of kernel/ear; and BHM-7 considering 1000-kernel weight and yield/plant. 
Correlation is also an important measurement indicating that traits which should be given importance to increase yield. In this experiment, two associations showed positive significant correlation: plant height with yield/plant and ear diameter with ear length (Table 3). Positive significant correlation between plant height and yield/plant had also been recorded by Salami et al. (2007) and Rafiq et al. (2010). This positive and significant association between the traits suggested additive genetic model thereby less affected by the environmental fluctuation. Besides, most of the associations were recorded as positive but non-significant. This type of association referred information of inherent relation among the pairs of combination. Positive and nonsignificant association between plant height with ear height and ear height with grain yield had also been observed by Olakojo and Olaoye (2011). Munawar et al. (2013) also studied positive, non-significant association between plant height with ear height and ear length. Positive and non-significant association for ear height with ear length and yield/plant was recorded by Rafiq et al. (2010). The negative insignificant association for number of kernels/ear with 1000-kernel weight referred a complex linked of relation among pair of combinations.

Table 4 indicated that variability within the maize genotypes is sufficiently divergent and constitutes potential candidate genotypes on which improvement program can be initiated. Phenotypic variance was higher than the genotypic variances for all the traits thus indicated the influences of environmental factor on these traits. Similar findings were observed by Salami et al. (2007), Bello et al. (2012) and Anshumanet al. (2013).The estimates of genotypic coefficient of variation (GCV) reflect the total amount of genotypic variability. Since most of the economic characters (grain yield) are complex in inheritance and are greatly influenced by several genes interacting with various environmental conditions, the study of phenotypic coefficient of variation (PCV) and genotypic coefficient of variation (GCV) is not only useful for comparing the relative amount of phenotypic and genotypic variations among different traits but also very useful to estimate the scope for improvement by selection. Table 4 indicated that for all traits PCV were higher than GCV. However, the differences between genotypic and phenotypic coefficient of variation indicated the environmental influence. In the present experiment, low value of GCV and PCV for plant height and ear height were recorded which was also observed by Anshuman et al. (2013).

Heritability estimates is of tremendous significance to the breeder, as its magnitude indicates the accuracy with which a genotype can be recognized by its phenotypic expression. Almost all traits studied here showed high heritability (Table 4). High heritability for ear length and 1000-kernel weight was also recorded by Noor et al. (2010). Aminu and Izge (2012) studied high heritability for plant height and yield/plant. Very high heritability (above 90\%) was observed for plant height, ear height, number of kernels/ear, 1000-kernel weight and yield/plant by Bello et al. (2012) and Anshuman et al. (2013).

Character exhibiting high heritability may not necessarily give high genetic advance. Johnson et al., (1955) showed high heritability should be accompanied by high genetic advance to arrive at more reliable conclusion. Bello et al. (2012) recorded higher genetic advance for plant height, number of kernels/ear and yield/plant. In the present study high heritability with high genetic advance was found for the trait number of kernels/ear and 1000-kernel weight which indicated the preponderance of additive gene action for the expression of these traits which is fixable in subsequent generations. The author suggested that these parameters were under the control of additive genetic effects. Sumathi et al. (2005) also suggested that these parameters could be manipulated according to requirements, and worthwhile improvement could be achieved through selection. However, high heritability and low genetic advance were observed for ear height, ear length and ear diameter which may be attributed to non-additive gene action governing these traits, and these characters could be improved through the use of hybridization and hybrid vigour.

Maize plant height, yield/plant, number of kernels/ear, 1000-kernel weight can be improved by selection, as these characters exhibited high genotypic and phenotypic coefficient of variations along with high heritability and genetic advance. Ear length, ear height and ear diameter had high heritability but the genetic coefficient of variations was low. This indicated that though, the character was highly heritable, its improvement through early generation selection may not give the desired results. Effective selection for superior genotypes is possible considering yield/plant, number of kernels/ear, 1000-kernel weight, plant and ear heights and can be used as target traits to improve maize grain yield.

Dendrogram grouped nine genotypes into three clusters (Fig 1). Maximum genotypes (four: BHM-9, BHM7, BHM-5 and V-92) were distributed under cluster II, followed by cluster III and cluster I containing three (Duranta, Uttaran and Sweet corn) and two (Popcorn and H-981) genotypes, respectively (Table 5). 
Subramanian and Subbaraman (2010) made dendrogram on 38 genotypes which results in four clusters: 14 genotypes under cluster 1, 13 under cluster 3, 9 under cluster 3 and remainder under cluster 4. 30 maize inbred lines were distributed by Azad et al. (2012) among six clusters. Another study was carried out by Chen et al. (2007) who reported that 186 maize genotypes could be classified into ten clusters.

\section{CONCLUSIONS}

Assessing of genetic diversity is the basic need for the utilization of any germplasm. The research findings suggested adequate genetic diversity exists among studied nine genotypes. Though BHM-7 performed well other genotypes were good enough considering different traits. All these genotypes can be utilized for further improvement of maize germplasm for the desired characters.

\section{ACKNOWLEDGEMENT}

This research was supported by the special grants of the Ministry of Science and Technology, Bangladesh, grant No.BS-43/2014.

\section{REFERENCES}

1. Ahmed S, 2007. Study of genetic diversity in maize inbreds, Annual Research Report, 2006-2007: Maize and Barley improvement, Plant Breeding Division, BARI, Joydebpur, Gazipur, pp: 16-18.

2. Ahmed S, 2013. Study on genetic diversity in maize (Zea mays L.) inbred lines for the development of hybrids, PhD Thesis, Department of Genetics and Plant Breeding, Bangladesh Agricultural University, Bangladesh.

3. Alika RW, ME Aken'ova and CA Fatokun, 1993. Variation among maize (Zea mays L.) accessions of Bendel State, Nigeria, Multivariate analysis of agronomic data. Euphytica, 66: 65-71.

4. Allard RW, 1960.Principles of Plant Breeding, John Wiley and Sons. Inc., New York.

5. Aminu D and AU Izge, 2012. Heritability and correlation estimates in maize (Zea mays L.) under drought conditions in Northern Guinea and Sudan Savannas of Nigeria.World Journal of Agricultural Sciences, 8: 598-602.

6. Anshuman V, NN Dixit, Dipika, SK Sharma and S Marker, 2013.Studies on heritability and genetic advance estimates in Maize genotypes.Bioscience Discovery, 4: 165-168.

7. Azad MAK, BK Biswas, N Alam and SS Alam, 2012. Genetic diversity in maize (Zea mays L.) inbred lines. The Agriculturists, 10: 64-70.

8. BBS 2011. Summery crop statistics and crop indices, Agriculture Wing, Bangladesh Bureau of Statistics, Ministry of Planning, Government of People's Republic of Bangladesh, Dhaka, pp. 37.

9. Bello OB, SA Ige, MA Azeez, MS Afolabi, SY Abdulmaliq and J Mahamood, 2012. Heritability and genetic advance for grain yield and its component characters in maize (Zea Mays L.).International Journal of Plant Research, 2: 138-145.

10. Burton GW, 1952.Quantitative inheritance in Grasses. Proceeding $6^{\text {th }}$ International Grassland Congress, 1: 277-283.

11. Chen FB, KC Yang, TZ Rong and GT Pan, 2007. Analysis of genetic diversity of maize hybrids in the regional tests of Sichuan and Southwest China, Acta Agronomica Sinica, 33: 991-998.

12. Comstock RE and HF Robinson, 1952. Genetic parameters, their estimate and significance, Proceedings $6^{\text {th }}$ International Grassland Congress, 1: 284-291.

13. Elahi NE, 2005. Effect of whole family training on maize cultivation in Bangladesh, CIMMYT, Bangladesh, House no.18, Road no.4, section 4,Uttara, Dhaka, Bangladesh.

14. Galarreta RJI and A Alvarez, 2001. Morphological classification of maize landraces from northern Spain.Genetic Resources and Crop Evolution, 48: 391-400.

15. GMR (Grain Market Report), 2014: International Grains Council (http://www.lgc.Int).

16. Hallauer AR and JB Mirinda-Filho, 1988.Quantitative genetic in maize breeding, $2^{\text {nd }}$ edition, lowa State University Press, Ames, USA.

17. Hanson G, HF Robinson and RE Comstock, 1956. Biometrical studies on yield in segregating population of Korean Lespedza, Agronomy Journal, 48: 268-274. 
18. Hoque MM, M Asaduzzaman, MM Rahman, S Zaman and SA Begum, 2008.Genetic divergence in maize (Zea mays L.). Bangladesh Journal Agricultural Research, 9: 145-148.

19. Hossain A and M Shahjahan, 2007. Grain quality evaluation of the major varieties or cultivar of maize, Annual Research Report: 2006-07, Post-Harvest Technology Division, Bangladesh Agricultural Research Institute (BARI), Gazipur, pp: 1-6.

20. Johnson HW, HF Robinson and RE Comstock, 1955.Estimates of genetic and environmental variability in soybean. Agronomy Journal, 47: 314-318.

21. Kadir MM, 2010.Development of quality protein maize hybrids and their adaption in Bangladesh, PhD thesis, Department of Genetics and Plant Breeding, Bangladesh Agricultural University.

22. Legesse BW, AA Myburg, KV Pixley and AM Botha, 2007. Genetic diversity of African maize inbred lines revealed by SSR markers. Hereditas, 144: 10-17.

23. Lucchin M, G Barcaccia and P Parrini, 2003. Characterization of a flint maize (Zea mays L.convar. mays) Italian landrace: I. Morpho-phenological and agronomic traits. Genetic Resources and Crop Evolution, 50: 315-327.

24. Melchinger AE, 1999.Genetic diversity and heterosis. In: JG Coors and S Pandey (Editors), The genetics and Exploitation of Heterosis in Crops. ASA, CSS and SSSA, Madison, Wisconsin. pp: 99118.

25. Munawar M, M Shahbaz, G Hammad and M Yasir, 2013. Correlation and path analysis of grain yields components in exotic maize (Zea mays L.) hybrids. International Journal of Sciences: Basic and Applied Research, 12: 22-27.

26. Noor M, H Rahman, Durrishahwar, M Iqbal, SMA Shah and I Ullah, 2010. Evaluation of maize half sib families for maturity and grain yield attributes. Sarhad Journal Agriculture, 26: 545-549.

27. Olakajo SA and G Olaoye, 2011. Correlation and heritability estimates of maize agronomic traits for yield improvement and Strigaasiatica (L) Kuntze tolerance. African Journal of Plant Science, 5: 365369.

28. Ortiz R, R Sevilla, G Alvarado and J Crossa, 2008. Numerical classification of related Peruvian highland maize races using internal ear traits. Genetic Resources and Crop Evolution, 55: 10551064.

29. Prasanna BM, SK Vasal, B Kassahun and NN Singh, 2001. Quality protein maize. Current Science, 81: 1308-1319.

30. Rafiq CM, M Rafique,A Hussain and M Altaf, 2010. Studies on heritability, correlation and path analysis in maize (Zea mays L.), Journal of Agricultural Research, 48: 35-38.

31. Salami AE, SAO Adegoke and OA Adegbite, 2007.Genetic variability among maize cultivars grown in Ekiti-State, Nigeria,Middle-East Journal of Scientific Research, 2: 9-13.

32. Shahrokhi M and KK Khorasani, 2013. Study of Morphological Traits, Yield and Yield Components on 28 Commercial Corn Hybrids (Zea mays L.). International Journal of Agronomy and Plant Production, 4: $2649-2655$.

33. Singh RK and BD Chaudhary, 1985. Biometrical method in quantitative genetic analysis, Kalyani Publisher, Ludhiana, New Delhi, pp: 54-57.

34. Subramanian A and N Subbaraman, 2010. Hierarchical cluster analysis of genetic diversity in Maize germplasm, Electronic Journal of Plant Breeding, 1(4): 431-436.

35. Sumathi P, A Nirmalakumariand K Mohanraj, 2005. Genetic variability and traits interrelationship studies in industrially utilized oil rich CIMMYT lines of maize (Zea mays L), Madras Agricultural Journal. 92: 612-617.

36. Taba S, J Diaz, J Franco and J Crossa, 1998. Evaluation of Caribbean maize accessions to develop a core subset. Crop Science, 37: 400-405.

37. Xia XC, JC Reif, AE Melchinger, M Frisch, DA Hoisington, D Beck, K Pixley and Warburton, 2005. Genetic diversity among CIMMYT maize inbred lines investigated with SSR markers: 2. Subtropical, tropical mid altitude, and high land maize inbred lines and their relationships with elite U.S. and European maize. Crop Science, 45: 2573-2582. 